\title{
MODELING FIRE PATHWAYS IN MONTANE GRASSLAND-FOREST ECOTONES
}

\author{
Joshua L. Conver ${ }^{*}$, Donald A. Falk ${ }^{1}$, Stephen R. Yool ${ }^{2}$, and Robert R. Parmenter ${ }^{3}$ \\ ${ }^{1}$ University of Arizona, School of Natural Resources and the Environment, \\ 1064 East Lowell Street, Tucson, Arizona, 85721, USA \\ ${ }^{2}$ University of Arizona, School of Geography and Development, \\ 1064 East Lowell Street, Tucson, Arizona, 85721, USA \\ ${ }^{3}$ Valles Caldera National Preserve, National Park Service \\ P.O. Box 359, Jemez Springs, New Mexico, 87025, USA
}

*Corresponding author: Tel.: +1-520-488-0731; e-mail: converjl@mail.uc.edu

\begin{abstract}
Fire plays a key role in regulating the spatial interactions between adjacent vegetation types from the stand to the landscape scale. Fire behavior modeling can facilitate the understanding of these interactions and help managers restore or maintain fire's natural role. The Valles Caldera National Preserve (VALL), in the Jemez Mountains of northern New Mexico, USA, contains one of the largest montane grasslands in North America and extensive areas of grassland-forest ecotone. We used the Minimum Travel Time (MTT) module in FlamMap to investigate the primary fire-growth vectors on the VALL landscape for the $50^{\text {th }}, 90^{\text {th }}$, and $99^{\text {th }}$ percentile of fire weather conditions. We evaluated whether modeled fire-growth vectors tended to follow the grassland-forest ecotone or if fire traveled directly across the grasslands and over the upland forest with a chi-square test. Our results indicated that the ecotone is a primary corridor for fire growth on the VALL landscape. Regular fire
\end{abstract}

\section{RESUMEN}

El fuego juega un rol en la regulación de las interacciones espaciales entre tipos de vegetación adyacente, desde escalas a nivel de rodal hasta de paisaje. La modelización del comportamiento del fuego puede facilitar la comprensión de estas interacciones y ayudar a los gestores a restaurar o mantener el rol natural del fuego. La Reserva de los Valles Caldera (VALL), en las montañas de Jemez en el norte de Nuevo Méjico, EEUU, contienen uno de los pastizales de montaña más grandes de Norteamérica, junto con áreas extensas de ecotono pastizal- bosque. Nosotros utilizamos el módulo de Tiempo Mínimo de Viaje (MTT por sus siglas en inglés) en FlamMap, para investigar los vectores de propagación primaria del fuego en el paisaje de VALL, para los percentiles de $50^{\circ}, 90^{\circ}$, y $99^{\circ}$ de las condiciones meteorológicas de fuego. Nosotros evaluamos, con un test de chi cuadrado, si los vectores de los modelos de propagación del fuego tendieron a seguir el ecotono-pastizal-bosque o si el fuego se propagó directamente a través de los pastizales y sobre el bosque de altitud. Nuestros resultados indicaron que el ecotono es un corredor primario para el crecimiento y propagación del fuego en el paisaje de los VALL. La propa- 
spread along the grassland-forest ecotone may help stabilize the boundary zone between these two dynamic communities by preventing forest encroachment into the grassland and maintaining an open stand structure. Identifying the dominant fire corridors will help land managers re-establish the spatial and process dynamics of the natural fire regime. gación regular del fuego a través del ecotono pastizal-bosque puede ayudar a estabilizar la zona límite entre estas dos comunidades dinámicas, previniendo la invasión del bosque en el pastizal y manteniendo en el rodal un tipo de estructura abierta. La identificación de los corredores dominantes de fuego ayudarán a los gestores del paisaje a restablecer los procesos dinámicos y espaciales del régimen natural de fuegos.

Keywords: disturbance, fire regimes, fuel, New Mexico, Pinus ponderosa, ponderosa pine, resiliency, Valles Caldera, vegetation dynamics

Citation: Conver, J.L., D.A. Falk, S.R. Yool, and R.R. Parmenter. 2018. Modeling fire pathways in montane grassland-forest ecotones. Fire Ecology 14(1): 17-32. doi: 10.4996/fireecology. 140117031

\section{INTRODUCTION}

Ecotones are zones of transition between adjacent ecological systems (diCastri et al. 1988, Delcourt and Delcourt 1992). The ecotone interface may take several forms that range from an open and diffuse mixing of adjacent vegetation types to a sharp contrast with little compositional or structural similarity. The contact zones between and among different fuel types on the landscape reflect the limiting factors that regulate the extent of the respective ecological communities. The occurrence and form of the ecotone between grassland and forest may be regulated by topography, edaphic factors, climate variability, or fire (Gosz and Sharpe 1989, Allen and Breshears 1998, Coop and Givnish 2007a). Interactions of these factors and the limiting thresholds that regulate the spatial extent of the vegetation mosaic determine the spatial and temporal dynamics of the contact zone (League and Veblen 2006), but it is likely that fluctuations in the ecotone are driven by changes in the frequency and intensity of extreme conditions rather than the variation around the mean conditions (Kitzberger 2012).

Fire history studies from tree-rings demonstrate that surface fires are frequent occurrenc- es in many western North American grassland-forest landscapes and contribute to regulating the location and composition of adjacent communities (Arno and Guell 1983, Archer 1994, Brown and Sieg 1999, Dewar 2011). Ecotones reciprocally influence fire behavior by contributing to the landscape mosaic of fuels, which may create either barriers or corridors for fire spread (Moritz et al. 2011). Fire plays a distinctive role in the grassland-forest ecotone by dynamically stabilizing the location of the interface of the two communities (Fisher et al.1987), limiting woody plant establishment through seedling mortality (Boren et al. 1997), facilitating rapid regeneration of grasses and forbs that outcompete woody vegetation (McPherson 1995), and maintaining species diversity (Peterson and Reich 2008). While the general role of fire occurrence in regulating forest-grassland ecotones has been established (Coop and Givnish 2008, Schoennagel et al. 2008), the spatial dynamics of fire movement through the ecotonal zone, especially in relation to landscape fuel heterogeneity, has not been investigated extensively.

There are three basic approaches to studying the dynamics of forest-grassland ecotones: vegetation and soil sampling, field experimentation, and modeling (Myster 2012). The lat- 
ter approach is a powerful tool to test hypotheses about the controls on fire behavior across a wide range of fuel and weather conditions (Stratton 2006, Keane et al. 2015, McKenzie and Perera 2015) and enables researchers to incorporate the relative roles of top-down and bottom-up influences on fire regimes (Keane et al. 2004). Weather is a primary top-down control on fire regimes because it affects a large spatial area, whereas the spatial pattern of fuels and ignitions act as a bottom-up control because there can be significant variation in arrangement across the landscape (Peters et al. 2004, Parisien et al. 2010).

One well-tested approach to modeling fire movements through a fuel complex is to determine the locations of dominant fire pathways using the minimum travel time (MTT) algorithm (Finney 2002) in the FlamMap fire model (Finney 2006). The MTT approach allows for an evaluation of the direction and rate of fire movement within and across the ecotone under a range of simulated fuel and weather conditions and can be compared to concomitant fire behaviors in the adjacent grasslands and forests. Previous studies used MTT algorithms for assessing fire risk within a wildland-urban interface (Bar Massada et al. 2009, Alcasena et al. 2015), identifying fire movement corridors in Brazilian savanna and pinescrub oak barrens (Mistry and Berardi 2005, Hajian et al. 2016), modeling the changes in fire behavior for different treatment scenarios (Ager et al. 2007, Drury et al. 2016), and for changing climates (Kalabokidis et al. 2015).

The purpose of our research was to examine the differential spread of fire in montane grasslands, conifer forests, and the intervening ecotone in order to determine the dominant fire-spread pathways. Specifically, we investigated the extent to which the ecotone functions as a primary corridor for fire movement across the landscape based on fuel properties, topography, and fire weather when compared to the adjacent grasslands and forests. We conducted this research in the 36000 ha Valles Caldera
National Preserve (VALL) in northern New Mexico, USA. The VALL is an ideal landscape for this study because of the large spatial extent, and the composition of the dominant vegetation communities are commonly found throughout the southern Rocky Mountains and Sky Islands of Arizona and northern Mexico. Understanding the factors that regulate fire spread pathways in this large forest-grassland complex will have relevance to landscape fire management in similar landscapes across western North America and elsewhere.

\section{METHODS}

\section{Study Area}

The Valles Caldera is a prominent volcanic feature in the Jemez Mountains, New Mexico, USA $\left(35^{\circ} 50^{\prime} \mathrm{N}, 106^{\circ} 30^{\prime} \mathrm{W}\right)$. The caldera bowl spans $24 \mathrm{~km}$ rim to rim and supports multiple forest community types across an elevational range of $2575 \mathrm{~m}$ a.s.l. to $3431 \mathrm{~m}$ a.s.l. (Figure 1). The VALL is well-suited for this research because it contains a mosaic of $>10800$ ha of grasslands and meadows, locally referred to as valles, surrounded by 24000 ha of forest that cover a resurgent dome and several lava domes, called cerros, within the caldera bowl (Goff 2009). In the past 20 years, >100 000 ha of the Jemez Mountains, including parts of the VALL, burned in major wildfires in 1996 (Dome Fire), 2000 (Cerro Grande Fire), 2011 (Las Conchas Fire), and 2013 (Thompson Ridge Fire).

In the VALL, the position of the grassland-forest ecotone generally corresponds to a topographic shift from steep mid-slope positions to shallowly sloping valle bottoms. The largest montane grasslands are found in the lowest $200 \mathrm{~m}$ of the elevation range and are composed of a mix of native bunchgrasses, including Parry's oatgrass (Danthonia parryi Scribn.) and Arizona fescue (Festuca arizonica Vasey). Rhizomatous grasses such as Kentucky bluegrass (Poa pratensis L.), woolly 


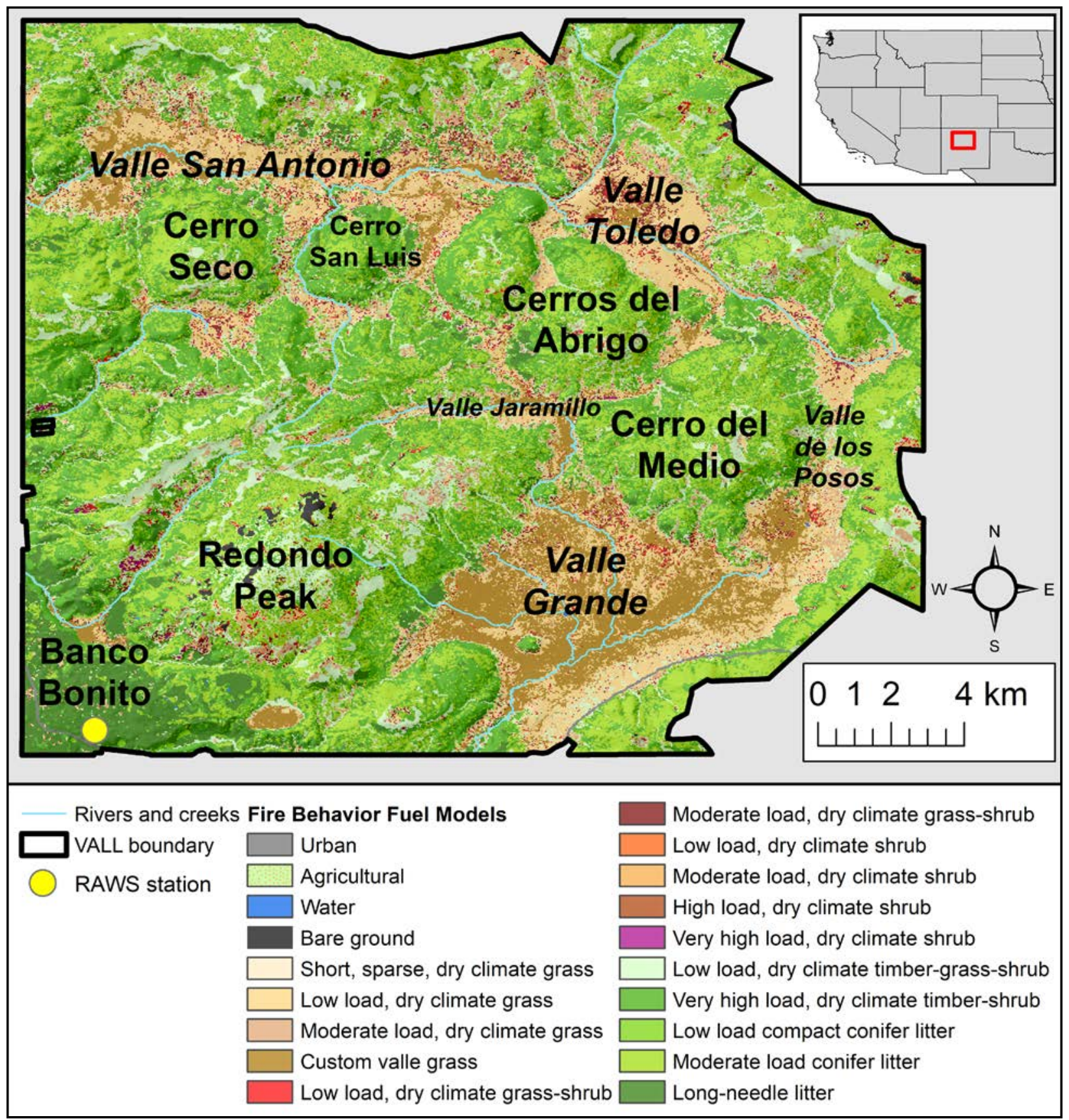

Figure 1. Place names, fuel models, and the location of the Jemez RAWS in the VALL. Elevations range from 2575 m a.s.l. in the Valle Grande to 3431 m a.s.l. on Redondo Peak. All creeks shown are perennial.

sedge (Carex utriculata Boott), and Idaho fescue (Festuca idahoensis Elmer) dominate mesic grassland sites. Ponderosa pine (Pinus ponderosa Engelm.) dominates the ecotonal forest bordering the montane grasslands on drier, south-facing and west-facing aspects, while Colorado blue spruce (Picea pungens
Engelm.) is found along the ecotones with north-facing and east-facing aspects. Douglas-fir (Pseudotsuga menziesii [Mirb.] Franco) and Engelmann spruce (Picea engelmannii Parry ex Engelm.) stands are found at higher elevations (Muldavin et al. 2006, Coop and Givnish 2007b). 
The climate of the VALL is typical of temperate continental regions in the southern Rocky Mountains. Temperature in July averaged $24.9^{\circ} \mathrm{C}$ and $3.4^{\circ} \mathrm{C}$ in January (Coop and Givnish 2007a). Annual precipitation averaged $640 \mathrm{~mm}$ at the forest-grassland ecotone (see http://www.wrcc.dri.edu/vallescaldera/) and is split evenly between the winter and summer months due to the association with the North American monsoon (Bowen 1996). Historically, most successful ignitions have been the result of dry lightning in May and June, although the four largest fires in the Jemez Mountains since 2000 were human caused. Convectional thunderstorms in July and August bring additional lightning and potential for successful ignition, although fire spread may be inhibited by higher fuel moistures and relative humidity. Monsoon rains recharge marshes and wetlands at the lowest elevations in the caldera bowl near the center of the Valle Grande. Wet meadows with perennial streams and permanent standing water are also present in the lowest elevations in the other major valles (Muldavin et al. 2006).

\section{Model Framework and Parameters}

We used a factorial process to simulate 270 fire pathways from three weather scenarios, three initial wind speeds and directions, and 10 ignition points. This process allowed for the modeling of fire pathways for a range of conditions without being overly complex. We calculated fire spread pathways using the MTT module in FlamMap v. 4 (Finney 2006). The MTT algorithm creates a vector representation of fire growth by calculating the time for fire to move from cell node to adjacent cell nodes (Finney 2006). Fire movement is defined by the shortest spread time from node to node. In effect, MTT pathways delineate the corridors of least resistance for fire growth based on the biotic and abiotic data contained in the landscape file and the wind and weather inputs. The landscape file is a composite of eight ras- ters: fire behavior fuel model (FBFM), slope, aspect, canopy cover, canopy height, canopy base height, canopy bulk density, and a digital elevation model.

We downloaded $30 \mathrm{~m}$ resolution rasters for the landscape file from the LANDFIRE data service (USGS 2010) with the exception of the FBFM layer, which was provided by the VALL. Staff at the VALL modified the FBFM to include a calibrated GR4 (moderate load, dry climate grass; Scott and Burgan 2005) fuel model that captured the higher live herbaceous and woody fuel moistures that are more appropriate for the lower elevation valle wetlands and along creeks (Figure 1, Table 1). With this exception, the modified fuel model retains all of the characteristics of the standard GR4 fuel model as specified in Scott and Burgan (2005).

Fuel moisture is an important input for the FlamMap modeling system. The Scott and Burgan (2005) fuel models employ a dynamic herbaceous component, meaning that live herbaceous fuel load is transferred to dead fuel load based on initial fuel moistures and a conditioning period that considers weather, aspect, slope, canopy cover, and elevation. FlamMap references these dynamic models and adjusts fuel moisture values for each cell on the landscape during the conditioning period. Our simulations were completed with a set conditioning period of 28 days based on the $50^{\text {th }}$ (average), 90 ${ }^{\text {th }}$ (dry), and $99^{\text {th }}$ (extreme) percentiles of weather conditions from the Jemez Remote Automated Weather Station (RAWS, $35^{\circ} 50^{\prime} 28^{\prime \prime}$ N, $106^{\circ} 37^{\prime} 8^{\prime \prime}$ ' W; Figure 1) for the primary fire season from 1966 to 2009 . We defined the fire season as the window when the Energy Release Component (ERC) was above the $90^{\text {th }}$ percentile of historic values, consistent with other modeling literature (Miller and Davis 2009, Davis et al. 2010). The VALL crossed this threshold on average on 1 April and 1 August for the 45-year period of record (Figure 2). We extended the modeled fire season through the month of August to account for the natural lag time of 100-hour and 1000- 
Table 1. Distribution of Scott and Burgan (2005) fuel models found in the VALL with the aggregated totals for grass, shrub, and timber fuel model categories.

\begin{tabular}{lccc|}
\hline Fuel name & Fuel model & Area $\left.\mathbf{( k m}^{2}\right)$ & Percentage of VALL \\
\hline Urban/developed & NB1 & 0.64 & 0.18 \\
Open water & NB8 & 0.12 & 0.03 \\
\hline Bare ground & NB9 & 1.10 & 0.31 \\
\hline Short, sparse dry climate grass & GR1 & 1.06 & 0.30 \\
\hline Low load dry climate grass & GR2 & 41.89 & 11.66 \\
\hline Moderate load dry climate grass & GR4 & 13.67 & 3.81 \\
\hline Modified GS4 valle wetland & CUS & 26.73 & 7.44 \\
\hline Low load dry climate grass shrub & GS1 & 3.55 & 0.99 \\
\hline Moderate load dry climate grass shrub & GS2 & 8.09 & 2.25 \\
\hline Low load dry climate shrub & SH1 & 0.03 & 0.01 \\
\hline Very high load dry climate shrub & SH7 & 0.68 & 0.19 \\
\hline Low load dry climate timber grass shrub & TU1 & 45.94 & 12.79 \\
\hline Very high load dry climate timber shrub & TU5 & 94.56 & 26.32 \\
\hline Low load compact conifer litter & TL1 & 1.04 & 0.29 \\
\hline Moderate load conifer litter & TL3 & 98.96 & 27.54 \\
\hline Long needle litter & TL8 & 21.25 & 5.91 \\
\hline Total & & 359.32 & 100.00 \\
\hline Aggregate categories & & & \\
\hline Grass & & 94.99 & 26.44 \\
\hline Shrub & & 0.71 & 0.20 \\
\hline Timber & & 261.75 & \\
\hline
\end{tabular}

hour fuels. Weather data were queried in FireFamily Plus 4.1 (Bradshaw 2013). At the start of the conditioning period, all fuels on the landscape, with the exception of the modified GS4 valle grass fuel, were assumed to be onethird cured for the average weather scenario and two-thirds cured for the dry and extreme weather scenarios; the modified GS4 fuel was assumed to be fully green for the average weather scenario and one-third cured for dry and extreme conditions (Helmbrecht 2012, Table 2). The modified GS4 fuel model retained the dynamic properties of the Scott and Burgan (2005) models.

We chose three prevailing wind directions as parameters for the simulations. According to the Jemez RAWS data, wind blew from 225,
245, and 265 degrees azimuth most frequently (Figure 3). These three directions represented more than $30 \%$ of the total days during the fire season, and no other direction accounted for more than $7 \%$ of fire season days. We selected three initial wind speeds of $8 \mathrm{~km} \mathrm{~h}^{-1}, 24 \mathrm{~km}$ $\mathrm{h}^{-1}$, and $48 \mathrm{~km} \mathrm{~h}^{-1}$ to represent calm, strong, and gusty situations, respectively. Initial wind speed and direction were modified using WindNinja (Forthofer 2007) to capture topographic influences on wind vectors (Figure 4). FlamMap imports the results from WindNinja to simulate fire pathways with more accurate local wind patterns.

Ignition points for this study were derived from a random selection of 10 actual ignition points from a database provided by the VALL 


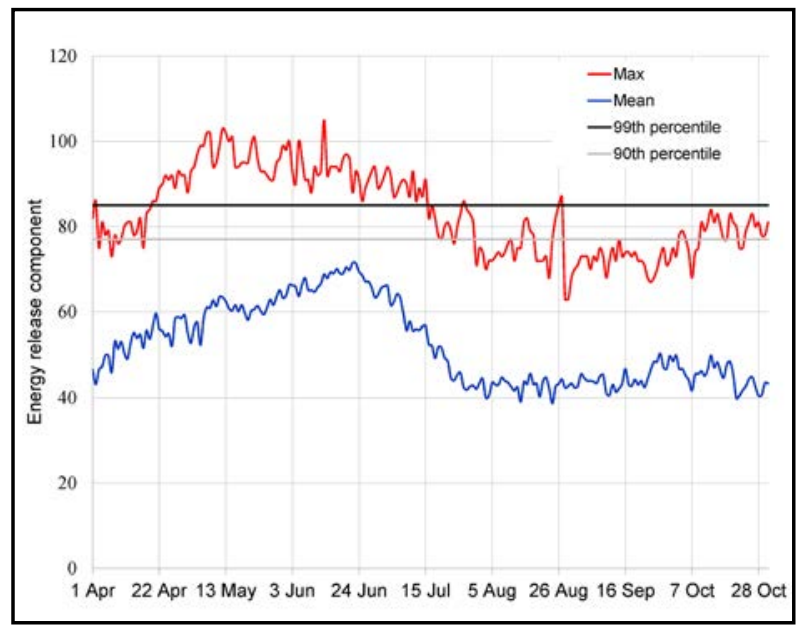

Figure 2. Daily energy release component (ERC) values from the Jemez RAWS station for the period 1966 to 2009, derived using FireFamily Plus. Fire season, defined when ERC exceeds the $90^{\text {th }}$ percentile value, begins on average on 1 April and ends on 1 August, but we extended the fire season to 1 September to account for the lag in 100-hour and 1000-hour fuels. Historical records show a bimodal fire season in extreme years. Time series values are for average (green line) and maximum (red line) observed ERC values. The $90^{\text {th }}$ percentile value is indicated by the gray line and the $97^{\text {th }}$ percentile value is indicated by the black line.

of 368 ignitions that resulted in fires greater than 0.05 ha from 1970 to 2003. Lightning was the most common source of ignition and made up the majority ( $55.5 \%, n=204)$ of total ignitions in the database (the remaining $44.6 \%, n=164$, were anthropogenic). Ear- ly-season and late-season ignition points received the same weight in the random selection process (Miller 2003).

\section{Statistical Methods}

We converted the vector pathways generated in MTT simulations to binary raster grids and summed them to determine the number of times each $30 \mathrm{~m}$ cell burned. Identifying the ecotone was key to this study, so we aggregated the FBFM raster into general fuel categories of unburnable, grass, shrub, and timber (Table 1) and extracted the values from the summed MTT raster for each fuel model category. The shrub fuel model category was dropped from the analysis because it represented less than $0.25 \%$ of the available fuel on the landscape. We used a chi-squared test to determine areas that were significant corridors for fire growth on the landscape. The expected value was calculated by multiplying the number of simulated fires by the proportion of grass and timber fuels (Table 3 ). Cells with grass fuel models were expected to burn 71.4 times and cells with timber fuel models were expected to burn 196.7 times. The sum of MTT pathways per cell represents the observed value. The chi-squared test does not incorporate differences in burning potential between grass and timber fuels; the test assumes that fire has an equal likelihood of occurring in every cell. Thus, the expected values are a

Table 2. Fuel moisture values for the three fire weather scenarios for the standard and modified fuel models. These values mirror Helmbrecht (2012). The other parameters of the modified valle fuel model are the same as the GR4 model.

\begin{tabular}{|c|c|c|c|c|c|c|}
\hline \multirow[b]{2}{*}{ Fuel component } & \multicolumn{3}{|c|}{ Modified valle fuel model } & \multicolumn{3}{|c|}{ Standard fuel models } \\
\hline & Average & High & Severe & Average & High & Severe \\
\hline 1-hour & 6 & 6 & 3 & 6 & 6 & 3 \\
\hline 10-hour & 7 & 7 & 4 & 7 & 7 & 4 \\
\hline 100-hour & 8 & 8 & 5 & 8 & 8 & 5 \\
\hline Live herbaceous & 120 & 120 & 90 & 90 & 60 & 60 \\
\hline Live woody & 150 & 150 & 120 & 120 & 90 & 90 \\
\hline
\end{tabular}




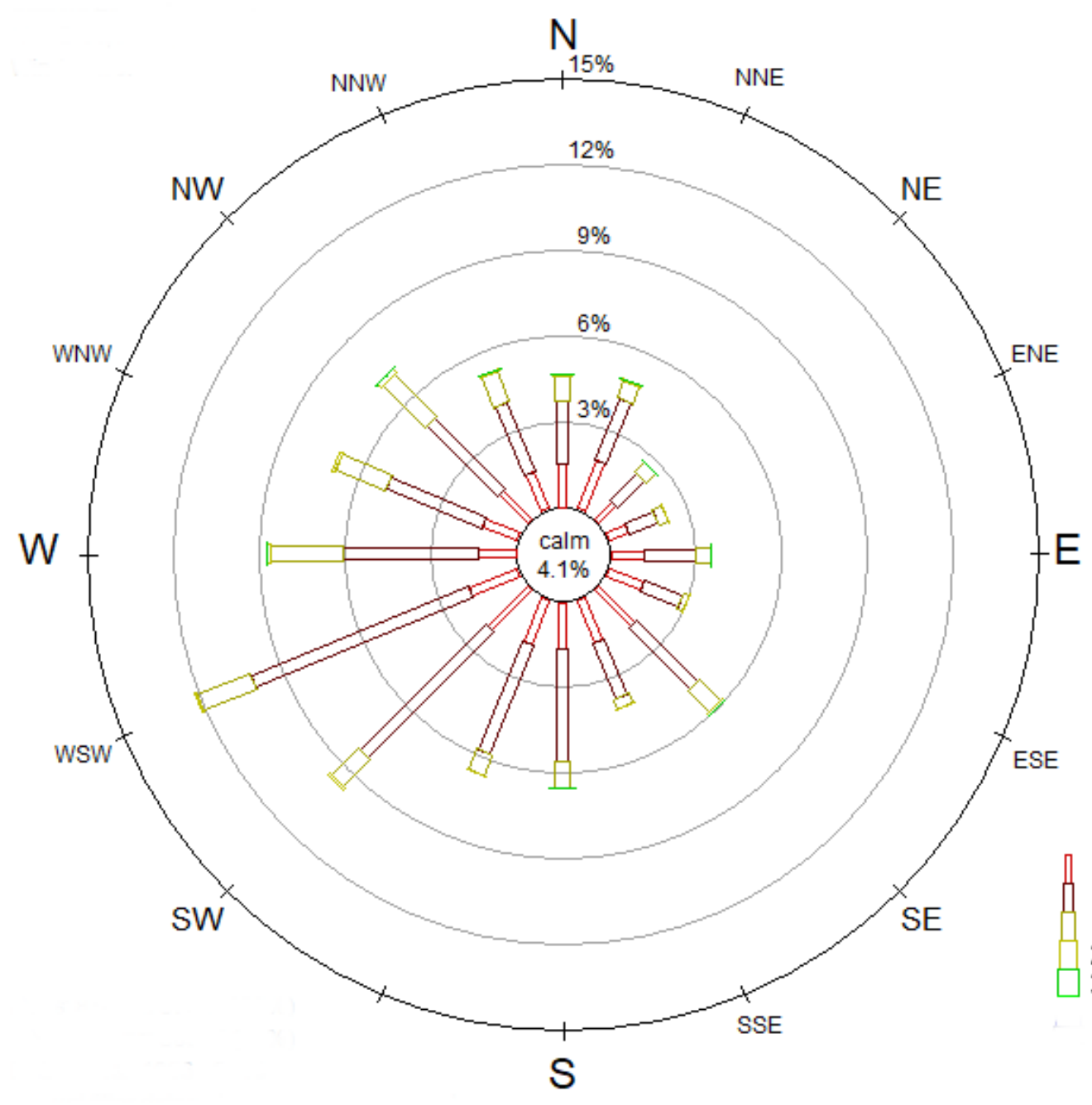

$\mathrm{km} \mathrm{hr}^{-1}$

0 to 6.50

6.51 to 13.00

13.01 to 20.99

21.00 to 30.50

30.51 to 40.23

Figure 3. Wind rose for daytime wind speed and direction during fire season from the Jemez RAWS station for the period 1 April to 31 August, 1966 to 2009, derived from FireFamily Plus. Length of bars is proportional to the percent of days with a given wind direction during fire season.

measure of the percentage of the aggregate fuel models on the landscape. In order to determine the proximity of significant cells to the ecotone, we calculated the distance from a given significant cell to the nearest opposite aggregate fuel model cell (e.g., grass to timber or timber to grass).

\section{RESULTS}

Fire-spread vectors tended to follow the forest-grassland ecotone (Figure 5) in most cases. The interior of the Valle Grande was relatively resistant to fire spread, apparently due to the high live fuel moistures associated with wetlands and riparian zones. In contrast, fire vectors followed forest-grassland ecotones on all sides of the Valle Grande (Figure 5). MTT vectors passed through the drier grassland fuels in other major valles. In the case of the Valle San Antonio and the Valle Toledo, the MTT pathways split into multiple vectors once the flaming front exited the narrow passage between cerros (Figure 5). These two valles contain patches of the GR4 fuel model modified with higher initial fuel mois- 


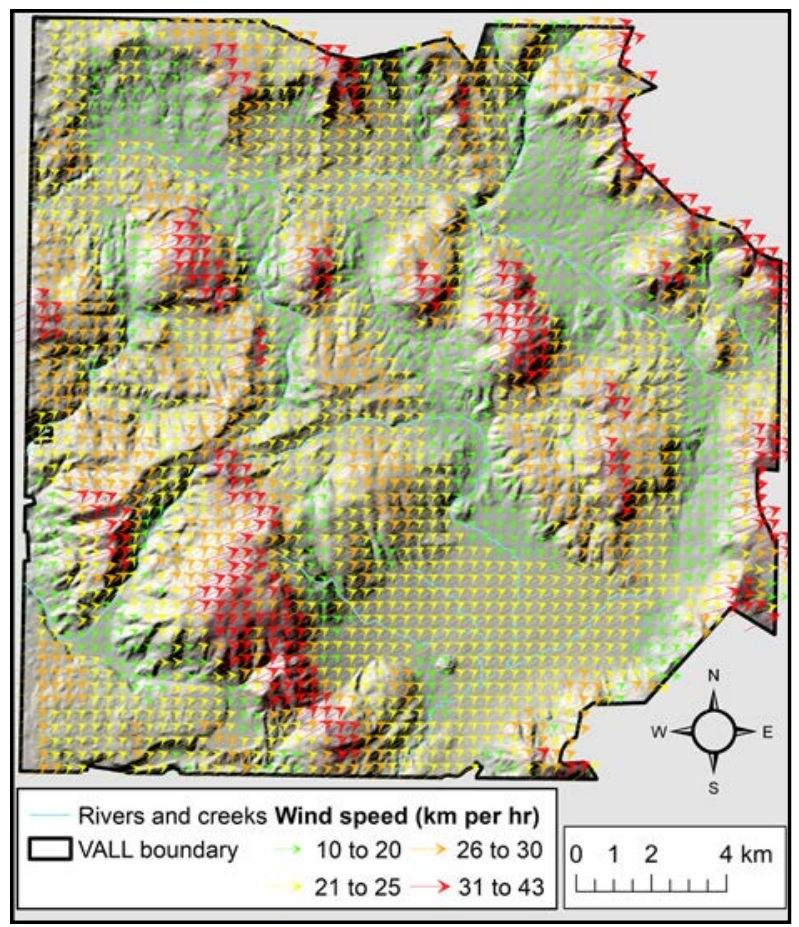

Figure 4. The wind vector output from WindNinja depicts the response of wind speed and direction to topography in the VALL. This figure depicts an incoming wind direction of 245 degrees and a speed of $24 \mathrm{~km} \mathrm{hr}^{-1}$. Notice how wind direction curves through the Valle Jaramillo and between the Cerro del Abrigo and the Cerros del Medio. This input to FlamMap simulates fire pathways with more accuracy.

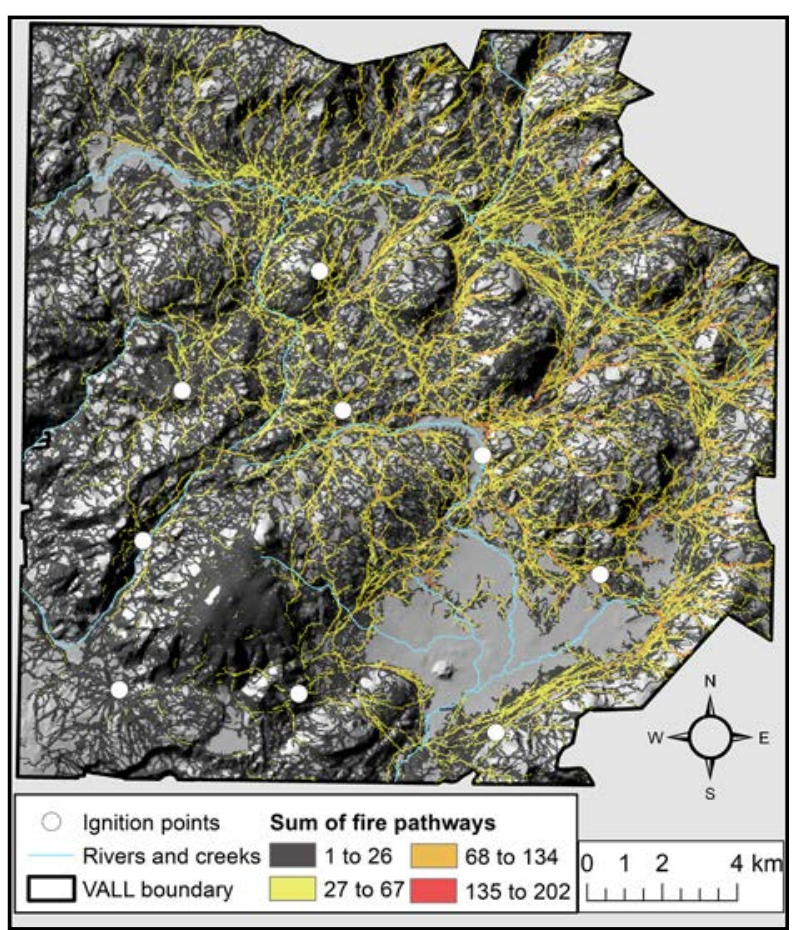

Figure 5. MTT fire spread pathways and locations of the random ignition points. Cells that burned in fewer than 27 simulations $(<10 \%$ of all simulations) are black, cells that burned in 27 to 67 simulations (10\% to $25 \%$ ) are yellow, 68 to 134 simulations (25\% to $50 \%$ ) are orange, and $>135$ simulations (>50\%) are red. Fire spread pathways are concentrated along ecotones between cerros and split into multiple vectors upon reaching the grasslands, but fire pathways exist at most elevations, which indicates that multiple areas of the landscape can carry fire.

Table 3. Expected fires per cell, proportion of the landscape for the aggregate fuel models, and expected and observed proportion of modeled fires for each category for the simulated fires. Since shrub fuel models were omitted from the chi-square test and are not presented in this table, the proportion of the landscape does not add to $100 \%$. Further, while we simulated 270 fires in total, the number of expected fires in the table does not sum to 270 because the remainder would be expected to occur in shrub fuels.

\begin{tabular}{lcc}
\hline Descriptor & Grass fuel models & Timber fuel models \\
\hline Number of cells & 105548 & 290835 \\
Proportion of landscape (\%) & 26.4 & 72.9 \\
Expected fires per cell & 71.3 & 196.8 \\
$\begin{array}{l}\text { Maximum observed number of fires in a cell } \\
\text { \% of simulated fires) }\end{array}$ & $182(67.4)$ & $202(74.8)$ \\
\hline
\end{tabular}


ture to capture the more mesic conditions in the center of the grasslands, and the MTT vectors went around, but not through, these areas. Fire was capable of crossing the interior of the drier northern valles of San Antonio and Toledo in the simulations, yet fire moved more easily closer to the grassland-forest ecotone. The creeks that flow east to west through these two valles presented a barrier to the fire pathways in some areas, most notably in the eastern Valle San Antonio.

While the MTT pathways showed a flammable landscape with many possible fire corridors, the ecotones were significant areas for fire movement. Of the 396383 cells within the study area, 2267 cells (0.3\%) burned enough times to be significant at the $P<0.05$ level (Figure 6). All of the significant cells were lo-

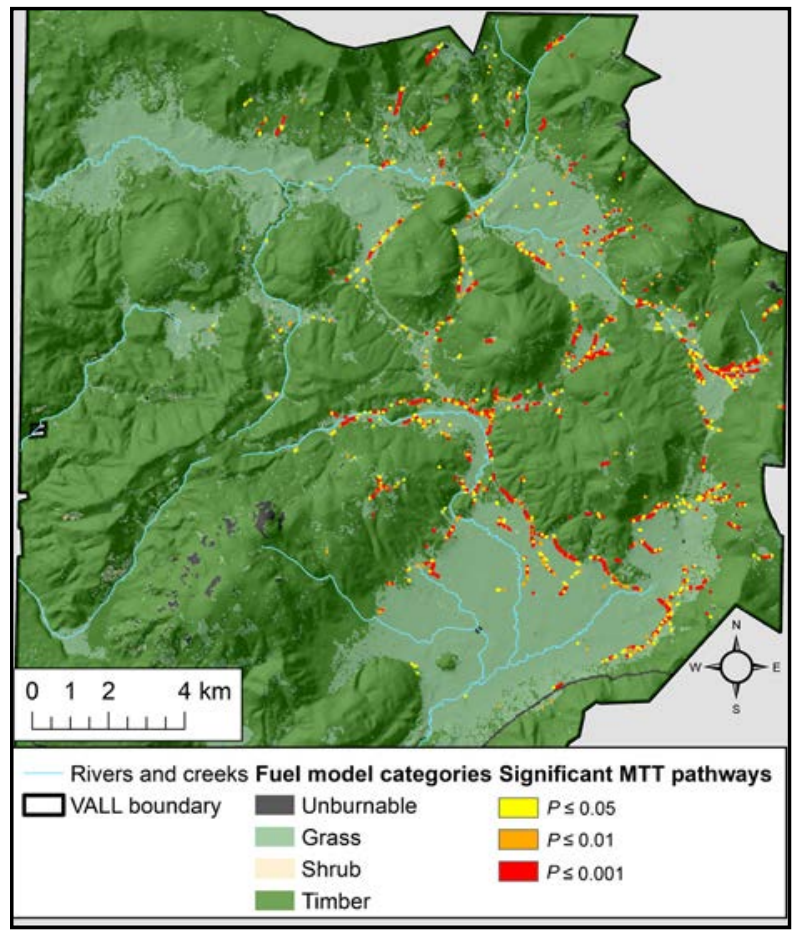

Figure 6. Statistically significant fire spread pathways for three levels of significance in the VALL as calculated by the chi-squared test. A total of 2267 cells $(0.3 \%$ of the VALL) burned significantly more than expected at the $P<0.05$ level, all of which were concentrated in the ecotone or dry fuels in some valles. cated in grass fuel models; nearly two-thirds of the significant cells shared a border with or were one cell (30 m) away from a cell with a timber fuel model, and $84 \%$ of significant cells were within $90 \mathrm{~m}$ of a timber fuel model cell (Figure 7; Table 4).

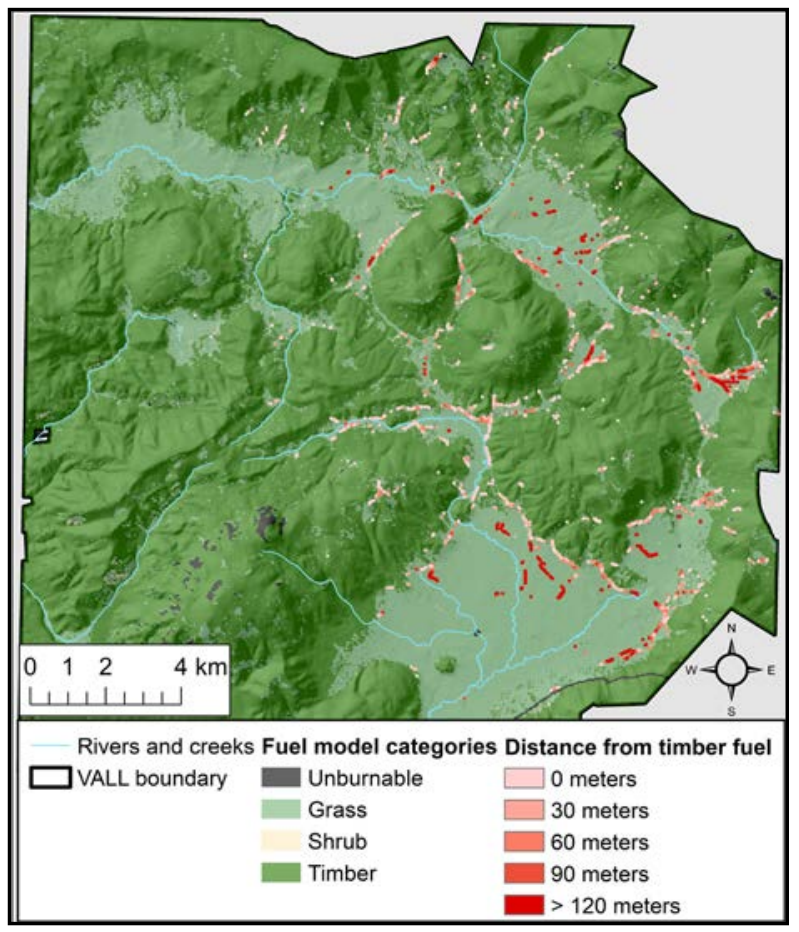

Figure 7. Distance from significant fire spread pathways to a timber fuel type. The majority of pathways (84\%) are in grass fuels within $90 \mathrm{~m}$ of a timber fuel model, indicating an ecotonal location.

\section{DISCUSSION}

Forest-grassland ecotones are significant corridors for fire growth on this landscape. The components of the combustion triangle (fuel, heat, oxygen) are optimized along the ecotone, including a continuous fuel bed of light, fine fuels that are consumed rapidly when dry to carry fire; lower fuel moistures than the valle bottoms due to the topographic position on the footslope of cerros; and wind vectors that follow the contours of topography. While we assigned higher initial live fuel moistures to the grasses at the lowest eleva- 
Table 4. Distance of significant fire pathway cells in grass fuel models to the nearest timber fuel model cell. Distance was determined by counting the number of cells between a significant cell and the nearest timber fuel model cell. Significance was determined by a chi-square test to at least the $P>0.05$ level and indicates that the grass fuel model burned more often than expected. Of the grass fuel model cells that burned more often than expected, $79 \%$ occurred within $60 \mathrm{~m}$ of a timber fuel model cell.

\begin{tabular}{lc}
\hline \multicolumn{1}{c}{$\begin{array}{c}\text { Distance from timber } \\
\text { fuel model cell }\end{array}$} & $\begin{array}{c}\text { Number (\%) of } \\
\text { significant cells }\end{array}$ \\
\hline $\begin{array}{l}\text { Adjacent to timber fuel } \\
\text { model }\end{array}$ & $832(36.7)$ \\
\hline One cell $(30 \mathrm{~m})$ & $685(30.2)$ \\
\hline Two cells $(60 \mathrm{~m})$ & $274(12.1)$ \\
\hline Three cells $(90 \mathrm{~m})$ & $120(5.3)$ \\
\hline Five or more cells $(>120 \mathrm{~m})$ & $356(15.7)$ \\
\hline Total & $2267(100.0)$ \\
\hline
\end{tabular}

tions of the valles, some of the live grass fuels would move into the dead fuel load category during the conditioning period. By using the selected initial fuel moisture parameters and dynamic conditioning of fuels based on actual observed weather, FlamMap pathways more accurately reflected the fire behavior of the life fuels. As a result, our simulations demonstrated that the wet interiors of the valle grasslands are not typically primary fire pathways under normal conditions. Valle Grande is the clearest example; our results suggest that the interior of the Valle Grande is relatively resistant to fire due to the strong influence of hydrologic and edaphic features despite having other characteristics that would promote low-intensity high-frequency fire behavior. Both operational observations of fire and fuel moisture sampling confirmed the initial fuel model parameters for both the standard fuel models and the wet meadows delineated by the modified GS4 fuel model. A prescribed fire executed in 2005 in the Valle Toledo, implemented under very dry fuel conditions in which 1-hour fuel moistures were approximately $4 \%$, did not burn into the riparian corridor (M. Rodriguez, National Park Service, Jemez Springs, New Mexico, USA, personal communication). Fuel moisture sampling during the 2011 Las Conchas Fire confirmed that the fuel moisture of live fuels in the center of the valles could be as high as $100 \%$ under the most severe fire weather conditions (Conver 2011).

Topography seems to be influential in determining the major fire corridors across this landscape in several ways. First, topography influences the spatial distribution of fuel types, especially on landscapes with substantial elevational gradients (Parks et al. 2012). Previous research in the VALL demonstrated that cold air drainage, in combination with high-frequency and low-intensity surface fire, controlled the location of the ecotone (Coop and Givnish 2007a, 2008). Second, the interaction of wind, fuel, and topography influences the behavior of fire corridors along the ecotone. Ponderosa pine stands allow wind to penetrate up to 10 tree heights from the forestecotone edge before wind speed slows (Rothermel 1983), but this distance may be reduced significantly for stands with a dense understory (Gaylor 1974). In contrast, the topography of the cerros deflects incoming wind vectors around the elevational gradient (Figure 4), which fosters the movement of fire through the ecotone.

In the ecotone, it is likely that the influence of topography is expressed through its effects of fuel types, mass, and condition. A study by Parks et al. (2012) that explicitly determined the contributions of ignitions, fuel, and topography on spatial fire patterns found that the fuel configuration was four times more important than topography for the nearby Gila-Aldo Leopold Wilderness Complex. That study did not explicitly examine the interaction between the grassland-forest fuel mosaic, but the study area contained large areas of both timber and grass fuels. Because FlamMap in- 
tegrates the multiple top-down and bottom-up factors during its calculations of MTT, determining the relative influence of each control, and how the influence has changed over time in the VALL, would be an opportunity for future research.

Our finding that ecotonal areas are important fire corridors is corroborated by a site-specific fire history study. Dewar (2011) sampled the ecotone and found minimum fire intervals of one year in all stands bordering the valles and mean fire intervals ranging from 2.69 years in the Valle Grande forests to 5.73 years in Valle Toledo. We suggest caution in extrapolating fire histories derived from ecotonal forest stands into upslope closed-canopy forest stands, especially given the location of significant MTT vectors close to the grassland-forest interface; however, frequent fire along the ecotone may have ecological ramifications for the resiliency of upslope forests.

High-frequency and low-intensity surface fire, especially in the drier ecotones dominated by ponderosa pine, would maintain the heterogeneous landscape pattern of fuel and provide a spatial and temporal buffer against catastrophic disturbance through the reduction of fuel accumulation over time, the maintenance of tall canopies, and the modulation of tree recruitment. Low-intensity fire has less likelihood of spreading into adjoining mesic mixed conifer sites during moderate drought years, especially in the southwestern US, and often requires exceptionally hot and dry conditions during the year of fire occurrence in order to burn across the topographically steep gradient (Margolis and Balmat 2009). Climate contributes to the regulation of the ecotone position through cold air drainage and increases the resiliency of the lower elevation grasslands to tree encroachment (Coop and Givnish 2007a), but fire keeps the parkland structure of xeric ecotonal forests intact and buffers upslope mixed conifer forests from experiencing the high fire severity as observed during the 2011 Las Conchas Fire. This suggests that the
VALL ecotones provide an example of a system that enhances resilience through a feedback between fire behavior and the landscape fuel mosaic.

While minimum temperature and frost determine the location of the low elevation ecotones (Coop and Givnish 2007a), frequent fire in the ecotone is a stabilizing variable that prevents forest encroachment into the grassland by removing young trees that might otherwise become established in the forested part of the ecotone, and thus maintaining a more open stand structure. Trees disappear towards the lower elevation grasslands and become denser as elevation increases away from the grasslands. By keeping the structure open, fire intensity would decrease at low slope positions. In normal or wet years, a low-intensity fire pathway would be less likely to spread upslope into adjacent forest types that can support stand-replacing fire. An open structure also has a positive feedback on spread patterns because grass fuels are drier than in the center of the valles, a continuous fuel bed with a gentle slope is present, and wind patterns consistently push fire into ecotonal areas around the cerros.

\section{CONCLUSIONS AND MANAGEMENT IMPLICATIONS}

In the VALL system, the grassland-forest ecotone is a conduit that carries fire efficiently across the landscape. In combination with edaphic and climatic factors, regular low-severity fire in the ecotone prevents tree incursion into the valles and thus helps to modulate the forest-grassland contact zone. Tree incursion in the VALL and surrounding area has been well-documented as fire frequencies have declined in the past century (Swetnam et al. 1999; Coop and Givnish 2007a, 2008). Understanding the most efficient pathways for fire growth can help land managers plan prescribed burns that mimic natural fire vectors and maintain the ecotone as a rich nexus of fire and biological activity. Given that fire fre- 
quency and size are increasing across the western United States and several large fires have occurred in the VALL this decade, restoration efforts could focus on establishing resiliency to the ecotonal forests. In order to accomplish this, land managers can use a combination of adaptive management strategies tailored to site-specific conditions and base treatments upon the best available science. Increasing the resiliency of the ecotone to fire will have implications for upslope forests and would contribute to the resilience of the entire landscape.

\section{ACKNOWLEDGEMENTS}

We thank M. Rodriguez from the VALL and D. Helmbrecht from the TEAMS Enterprise for sharing data and knowledge about the study site. T. Nicolet and C. Frost provided excellent preliminary reviews and many helpful comments. Thank you to the two anonymous reviewers for their suggestions to improve this manuscript. This work was supported by the Joint Fire Science Program (06-3-1-27) and the USDA Forest Service Rocky Mountain Research Station (RJVA 09JV-11221637-22).

\section{LITERATURE CITED}

Ager, A.A., M.A. Finney, B.K. Kerns, and H. Maffei. 2007. Modeling wildfire risk to northern spotted owl habitat in central Oregon, USA. Forest Ecology and Management 246: 45-56. doi: 10.1016/j.foreco.2007.03.070

Alcasena, F.J., M. Salis, and C. Vega-Garcia. 2016. A fire modeling approach to assess wildfire exposure of valued resources in central Navarra, Spain. European Journal of Forest Research 135(1): 87-107. doi: 10.1007/s10342-015-0919-6

Allen, C.D., and D.D. Breshears. 1998. Drought-induced shift of a forest-woodland ecotone: rapid landscape response to climate variation. Proceedings of the National Academy of Science of the United States of America 95: 14839-14842. doi: 10.1073/pnas.95.25.14839

Archer, S. 1994. Woody plant encroachment into Southwestern grasslands and savannas: rates, patterns, and proximate causes. Pages 13-68 in: M. Varva, W.A. Laycock, and R.D. Pieper, editors. Ecological implications of livestock herbivory in the West. Society for Range Management, Denver, Colorado, USA.

Arno, S.F., and G.E. Gruell. 1983. Fire history at the forest-grassland ecotone in southwestern Montana. Journal of Range Management 36: 332-336. doi: 10.2307/3898481

Bar Massada, A., V.C. Radeloff, S.I. Stewart, and T.J. Hawbaker. 2009. Wildfire risk in the wildland-urban interface: a simulation study in northwestern Wisconsin. Forest Ecology and Management 258: 1990-1999. doi: 10.1016/j.foreco.2009.07.051

Boren, J.C., D.M. Engle, M.S. Gregory, R.E. Masters, T.G. Bidwell, and V.A. Mast. 1997. Landscape structure and change in a hardwood forest-tall-grass prairie ecotone. Journal of Range Management 50: 244-249. doi: 10.2307/4003723

Bowen, B.M. 1996. Rainfall and climate variation over a sloping New Mexico plateau during the North American monsoon. Journal of Climate 9: 3432-3442. doi: 10.1175/1520-0442(1996)009<3432:RACVOA>2.0.CO;2

Bradshaw, L. 2013. FireFamily Plus 4.1. USDA Forest Service, Rocky Mountain Research Station, Fire Sciences Laboratory, Missoula, Montana, USA. <http:/www.firelab.org/project/ firefamilyplus>. Accessed 1 January 2018. 
Brown, P.M., and C.H. Sieg. 1999. Historical variability in fire at the ponderosa pine-northern Great Plains prairie ecotone, southeastern Black Hills, South Dakota. Ecoscience 6: 539547. doi: 10.1080/11956860.1999.11682563

Conver, J.L. 2011. Stochastic fire modeling of a montane grassland-forest landscape in the Valles Caldera National Preserve, New Mexico, USA. Thesis, University of Arizona, Tucson, USA.

Coop, J.D., and T.J. Givnish. 2007a. Spatial and temporal patterns of recent forest encroachment in montane grasslands of the Valles Caldera, New Mexico, USA. Journal of Biogeography 34: 914-927. doi: 10.1111/j.1365-2699.2006.01660.x

Coop, J.D., and T.J. Givnish. 2007b. Gradient analysis of reversed treelines and grasslands of the Valles Caldera, Jemez Mountains, New Mexico. Journal of Vegetation Science 18: 4354. doi: 10.1111/j.1654-1103.2007.tb02514.x

Coop, J.D., and T.J. Givnish. 2008. Constraints on tree seedling establishment in montane grasslands of the Valles Caldera, New Mexico. Ecology 89: 1101-1111. doi: 10.1890/06-1333.1

Davis, B.H., C. Miller, and S.A. Parks. 2010. Retrospective fire modeling: quantifying the impacts of fire suppression. USDA Forest Service General Technical Report RMRS-GTR236WWW, Rocky Mountain Research Station, Fort Collins, Colorado, USA.

Delcourt, P.A., and H.R. Delcourt. 1992. Ecotone dynamics in space and time. Pages 19-54 in: A.J. Hansen and F. diCastri, editors. Landscape boundaries: consequences for biotic diversity and ecological flows. Springer, New York, New York, USA. doi: 10.1007/978-1-4612-28042_2

Dewar, J.J. 2011. Fire history of montane grasslands and ecotones of the Valles Caldera, New Mexico, USA. Thesis, University of Arizona, Tucson, USA.

diCastri, F., A.J. Hansen, and M.M. Holland. 1988. A new look at ecotones, emerging international projects on landscape boundaries. International Union of Biological Sciences 17: $1-163$.

Drury, S.A., H.M. Rauscher, E.M. Banwell, S. Huang, and T.L. Lavezzo. 2016. The interagency fuels treatment decision support system: functionality for fuels treatment planning. Fire Ecology 12(1): 103-123. doi: 10.4996/fireecology.1201103

Finney, M.A. 2002. Fire growth using minimum travel time methods. Canadian Journal of Forest Research 32: 1420-1424. doi: 10.1139/x02-068

Finney, M.A. 2006. An overview of FlamMap fire modeling capabilities. Page 41 in: P.L. Andrews and B.W. Butler, editors. Fuels management-how to measure success: conference proceedings. USDA Forest Service RMRS-P-41, Rocky Mountain Research Station, Fort Collins, Colorado, USA.

Fisher, R.F., M.J. Jenkins, and J.W. Fisher. 1987. Fire and the prairie-forest mosaic of Devil's Tower National Monument. The American Midland Naturalist 117: 250-257. doi: $10.2307 / 2425966$

Forthofer, J.M. 2007. Modeling wind in complex terrain for use in fire spread prediction. Thesis, Colorado State University, Fort Collins, Colorado, USA.

Gaylor, H.P. 1974. Wildfires: prevention and control. Prentice-Hall Publishing, Bowie, Maryland, USA.

Goff, F. 2009. Valles Caldera: a geologic history. University of New Mexico Press, Albuquerque, USA.

Gosz, J.R., and P.J. Sharpe. 1989. Broad-scale concepts for interactions of climate, topography, and biota at biome transitions. Landscape Ecology 3: 229-243. doi: 10.1007/BF00131541 
Haijan, M., E. Melachrinoudis, and P. Kubat. 2016. Modeling wildfire propagation with the stochastic shortest path: a fast simulation approach. Environmental Modelling \& Software 82: 73-88. doi: 10.1016/j.envsoft.2016.03.012

Helmbrecht, D. 2012. Valles Caldera National Preserve landscape restoration and management plan. USDA Forest Service, TEAMS Enterprise, Missoula, Montana, USA.

Kalabokidis, K., P. Palaiologou, E. Gerasopoulous, C. Giannakopoulos, E. Kostopoulou, and C. Zerefos. 2015. Effect of climate change projections on forest fire behavior and values-at-risk in southwestern Greece. Forests 6: 2214-2240. doi: 10.3390/f6062214

Keane, R.E., G.J. Cary, I.D. Davies, M.D. Flannigan, R.H. Gardner, S. Lavorel, J.M. Lenihan, C. Li, and T.S. Rupp. 2004. A classification of landscape fire succession models: spatial simulations of fire and vegetation dynamics. Ecological Modeling 179: 3-27. doi: 10.1016/j.ecolmodel.2004.03.015

Keane, R.E., E. Smithwick, D. McKenzie, C. Miller, D.A. Falk, and L.B. Kellogg. 2015. Representing climate, disturbance, and vegetation interactions in landscape simulation models. Ecological Modelling 309: 33-47. doi: 10.1016/j.ecolmodel.2015.04.009

Kitzberger, T. 2012. Ecotones as complex arenas of disturbance, climate, and human impacts: the trans-Andean forest-steppe ecotone of northern Patagonia. Pages 59-88 in: R.W. Myster, editor. Ecotones between forest and grassland. Springer, New York, New York, USA. doi: 10.1007/978-1-4614-3797-0_3

League, K., and T. Veblen. 2006. Climatic variability and episodic Pinus ponderosa establishment along the forest-grassland ecotones of Colorado. Forest Ecology and Management 228(1): 98-107. doi: 10.1016/j.foreco.2006.02.030

Margolis, E.Q., and J. Balmat. 2009. Fire history and fire-climate relationships along a fire regime gradient in the Santa Fe Municipal Watershed, NM, USA. Forest Ecology and Management 258: 2146-2430. doi: 10.1016/j.foreco.2009.08.019

McKenzie, D., and A.H. Perera. 2015. Modeling wildfire regimes in forest landscapes: abstracting a complex reality. Pages 73-92 in: A.H. Perera, B.R. Sturtevant, and L.J. Buse, editors. Simulation modeling of forest landscape disturbances. Springer, Cham, Switzerland. doi: 10.1007/978-3-319-19809-5_4

McPherson, G.R. 1995. The role of fire in the desert grasslands. Pages 130-151 in: M.P. McClaran, and T.R. Van Devender, editors. The desert grassland. University of Arizona Press, Tucson, Arizona, USA.

Miller, C. 2003. The spatial context of fire: a new approach for predicting fire occurrence. Pages 22-29 in: K.E.M. Galley, R.C. Kinger, and N.G. Sugihara, editors. Proceedings of fire conference 2000: the first national congress on fire ecology, prevention, and management. Tall Timbers Research Station Miscellaneous Publication 13.

Miller, C., and B. Davis. 2009. Quantifying the consequences of fire suppression in two California national parks. The George Wright Forum 26: 76-88.

Mistry, J., and A. Berardi. 2005. Assessing fire potential in a Brazilian savanna nature reserve. Biotropica 37: 439-451. doi: 10.1111/j.1744-7429.2005.00058.x

Moritz, M.A., P.F. Hessburg, and N.A. Povak. 2011. Native fire regimes and landscape resilience. Pages 51-88 in: D. McKenzie, C. Miller, and D.A. Falk, editors. The landscape ecology of fire. Springer, New York, New York, USA. doi: 10.1007/978-94-007-0301-8_3

Muldavin, E., P. Tonne, C. Jackson, and T. Neville. 2006. A vegetation map of the Valles Caldera National Preserve, New Mexico. Final report for Cooperative Agreement (01CRAG0014). University of New Mexico, Natural Heritage Museum, Albuquerque, New Mexico, USA. 
Myster, R.W., editor. 2012. Ecotones between forest and grassland. Springer, New York, New York, USA. doi: 10.1007/978-1-4614-3797-0

Parisien, M.A., C. Miller., A.A. Ager, and M.A. Finney. 2010. Use of artificial landscapes to isolate controls on burn probability. Landscape Ecology 25: 79-93. doi: 10.1007/ s10980-009-9398-9

Parks, S.A., M.A. Parisien, and C. Miller. 2012. Spatial bottom-up controls on fire likelihood vary across western North America. Ecosphere 3(1): 1-20. doi: 10.1890/ES11-00298.1

Peters, D.P.C., R.A. Pielke, B.T. Bestelmeyer, C.D. Allen, S. Munson-McGee, and K.M. Havstad. 2004. Cross-scale interactions, nonlinearities, and forecasting catastrophic events. Proceedings of the National Academy of Science 101: 15130-15135. doi: 10.1073/pnas.0403822101

Peterson, D.W., and P.B. Reich. 2008. Fire frequency and tree canopy structure influence plant species diversity in a forest-grassland ecotone. Plant Ecology 194(1): 5-16. doi: 10.1007/ s11258-007-9270-4

Rothermel, R.C. 1983. How to predict the spread and intensity of forest and range fires. USDA Forest Service General Technical Report INT-143, Intermountain Forest and Range Experimental Station, Ogden, Utah, USA.

Schoennagel, T., E.A. Smithwick, and M.G. Turner. 2008. Landscape heterogeneity following large fires: insights from Yellowstone National Park, USA. International Journal of Wildland Fire 17: 742-753. doi: 10.1071/WF07146

Scott, J.H., and R.E. Burgan. 2005. Standard fire behavior fuel models: a comprehensive set for use with Rothermel's surface fire spread model. USDA Forest Service General Technical Report RMRS-GTR-153, Rocky Mountain Research Station, Fort Collins, Colorado, USA.

Stratton, R.D. 2006. Guidance on spatial wildland fire analysis: models, tools, and techniques. USDA Forest Service General Technical Report RMRS-GTR-183, Rocky Mountain Research Station, Fort Collins, Colorado, USA.

Swetnam, T.W., C.D. Allen, and J.L. Betancourt. 1999. Applied historical ecology: using the past to manage for the future. Ecological Applications 9: 1189-1206. doi: 10.1890/1051-0761(1999)009[1189:AHEUTP]2.0.CO;2

USGS [US Department of the Interior, Geological Survey]. 2010. LANDFIRE spatial data product server. <http://www.landfire.gov/index.php>. Accessed 17 May 2010. 